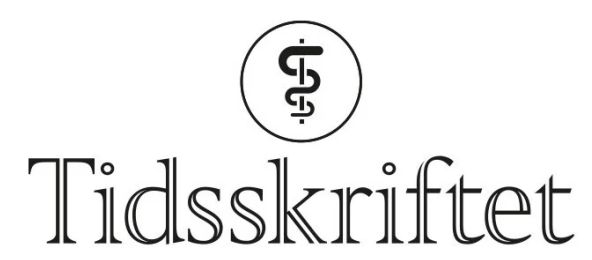

DEN NORSKE LEGEFORENING

\title{
Å. Tangerud svarer
}

KOMMENTAR

\section{ÅSE TANGERUD}

aastan@ous-hf.no

Åse Tangerud er spesialist i radiologi og overlege ved Avdeling for radiologi og nukleærmedisin, Oslo universitetssykehus, Radiumhospitalet.

Forfatteren har ikke oppgitt noen interessekonflikter.

Vi takker Vegard Heimly Brun og Olav Inge Håskjold for positive og konstruktive tilbakemeldinger på vår artikkel.

Brun og Håskjold reflekterer rundt hvilke behandlere som bør vurdere knuter i tyreoidea etter klassifikasjonssystemet TIRADS. De skriver at TIRADS er en «logaritme», men vi antar selvfølgelig at de mener en algoritme (altså en oppskrift). Vi mener at denne algoritmen er et godt hjelpemiddel for leger som utfører ultralydundersøkelser. TIRADS gir klare retningslinjer om hvilke knuter som er benigne og hvilke som trenger videre utredning med finnålscytologi. Vi er enige i at den er spesielt nyttig for leger uten god erfaring $i$ ultralyd av tyreoidea, men vil også være til hjelp for de mer erfarne. Dessuten er det ikke slik at TIRADS forhindrer erfarne leger i å gjøre mer detaljerte vurderinger og beskrivelser.

For øvrig bruker spesialister (kompetansesentre) innen forskjellige kreftformer i økende grad standardiserte rapporteringssystemer, for eksempel bryst (BIRADS), prostata (PIRADS), blære (VIRADS).

Takk også for henvisning til interessant artikkel publisert i Thyroid juli 2020 etter at vår artikkel var akseptert.

Publisert: 12. oktober 2020. Tidsskr Nor Legeforen. DOI:10.4045/tidsskr.20.0743

(C) Tidsskrift for Den norske legeforening 2023. Lastet ned fra tidsskriftet.no 26. april 2023. 